\title{
AN EXPERIMENTAL STUDY ON DURABILITY AND WATER ABSORPTION PROPERTIES OF PERVIOUS CONCRETE
}

\author{
Darshan S. Shah ${ }^{1}$, Jayeshkumar Pitroda ${ }^{2}$ \\ ${ }^{1}$ Student of final year M.E. (C.E M), B.V.M Engineering College, Vallabh Vidyanagar \\ ${ }^{2}$ Assistant Professor and Research Scholar, Civil Engineering Department, B.V.M. Engineering College, Vallabh \\ Vidyanagar-Gujarat-India
}

\begin{abstract}
Pervious concrete is a special high porosity concrete used for flatwork applications that allows water from precipitation and other source to pass through there by Reducing the Runoff from a site and Recharging Ground Water Levels. Durability and Water Absorption are important properties of Pervious Concrete. This paper represents the experimental methodology and experimental results related to durability and water absorption. Cylinders of size $100 \mathrm{~mm} \emptyset$ and $200 \mathrm{~mm}$ height are prepared to investigate both these properties. This investigation should be carried out at the end of 28 days for water absorption and 56 days for durability in which cylinders are immersed in Sodium Chloride ( $\mathrm{NaCl}$ ) Solution after 28 days of casting. Different concrete mix proportion such as 1:6, 1:8 and 1:10 with different size of gravel such as $18.75 \mathrm{~mm}$ and $9.375 \mathrm{~mm}$ should be used to check both these properties of pervious concrete. Test results indicates that pervious concrete made by 1:6 concrete mix proportion has more durability and less water absorption and pervious concrete made by 1:10 mix proportion has more water absorption and less durability that's why durability and water absorption are inversely proportional to each other.
\end{abstract}

Keywords: Pervious concrete, porosity, durability, water absorption, sodium chloride solution

\section{INTRODUCTION}

Pervious Concrete is a special type of concrete in which no fine aggregates are used and gravel has been used in place of the coarse aggregate. Pervious Concrete is a homogeneous mixture of cement, aggregate / gravel and water. Pervious Concrete is also called as "no-fines" concrete. Cylinders of size $100 \mathrm{~mm}$ diameter and $200 \mathrm{~mm}$ height are made for an experimental investigation of Water Absorption and Durability of Pervious Concrete.

Concrete Durability is one of the most important considerations in the design of new structures and when assessing the condition of existing structures. Concrete construction is becoming increasingly complex and the importance of producing structures that are both cost effective and durable has never been higher. The main purpose of durability is about minimising the rate of deterioration. Durability of Concrete is related to the design process, specification of materials, workmanship, environmental effects, accidents and repairs. In Water Absorption Test cylinders are cured in curing pond for 28 days and weighing it \& \% water absorption is to be determined. In Durability Test cylinders are first cured in curing pond for 28 days and then after weighing it is again immersed in "Sodium Chloride Solution" for another 28 days.
The Durability of Concrete is the resistance of concrete to weathering action, chemical attack, abrasion and other degradation processes. The Water Absorption of Concrete is the procedure that involves drying a specimen to a constant weight, weighing it, immersing it in water for specified amount of time, and weighing it again. The increase in weight as a percentage of the original weight is expressed as its absorption (in percent). The average absorption of the test samples shall not be greater than $5 \%$ with no individual unit greater than $7 \%$.

\section{EXPERIMENTAL MATERIALS}

Pervious Concrete is a mixture of Cement, Coarse Aggregate / Gravel and Water. No Fine Aggregates are used for making pervious concrete. Sometimes microfibers and admixtures are used to achieve adequate strength and durability of pervious concrete. Pervious Concrete has been casted with different concrete mix proportion such as 1:6, 1:8 and 1:10 with 18.75 $\mathrm{mm}$ and $9.375 \mathrm{~mm}$ gravel size with OPC 53 Grade and PPC 53 Grade Cement. 
Table 1: physical properties of ordinary portland cement 53 grade (opc) \& pozzolona portland cement 53 grade (ppc)

\begin{tabular}{|c|c|c|c|}
\hline Property & $\begin{array}{c}\text { Value for Cement } \\
\text { for OPC }\end{array}$ & $\begin{array}{c}\text { Value for Cement } \\
\text { for PPC }\end{array}$ & $\begin{array}{c}\text { IS Code Recommendations } \\
\text { IS : 12269-1987 }\end{array}$ \\
\hline Specific Gravity & 3.15 & 2.93 & $3.10-3.15$ \\
\hline Consistency (\%) & $28 \%$ & $31.5 \%$ & $30-35(\%)$ \\
\hline Initial setting time (min) & 35 minutes & 35 minutes & 30 minimum minutes \\
\hline Final setting time (min) & 178 minutes & 230 minutes & 600 maximum minutes \\
\hline $\begin{array}{c}\text { Compressive strength at } 7 \text { days } \\
\left(\mathrm{N} / \mathrm{mm}^{2}\right)\end{array}$ & $38.49 \mathrm{~N} / \mathrm{mm}^{2}$ & $38.49 \mathrm{~N} / \mathrm{mm}^{2}$ & $43 \mathrm{~N} / \mathrm{mm}^{2}$ \\
\hline $\begin{array}{c}\text { Compressive strength at } 28 \text { days } \\
\left(\mathrm{N} / \mathrm{mm}^{2}\right)\end{array}$ & $52.31 \mathrm{~N} / \mathrm{mm}^{2}$ & $51 \mathrm{~N} / \mathrm{mm}^{2}$ & $53 \mathrm{~N} / \mathrm{mm}^{2}$ \\
\hline
\end{tabular}

Source : B.V.M. Engineering College, Structural Engineering Department, V.V.Nagar, Anand

Table 2: chemical compositions of ordinary portland cement 53 grade (opc) \& pozzolona portland cement 53 grade (ppc)

\begin{tabular}{|c|c|c|}
\hline Oxide & Content (\%) in OPC & Content (\%) in PPC \\
\hline Lime $\mathrm{CaO}$ & $60-67$ & 47.0 \\
\hline Silica $\mathrm{SiO}_{2}$ & $17-25$ & 23.5 \\
\hline Alumina $\mathrm{Al}_{2} \mathrm{O}_{3}$ & $3-8$ & 12.9 \\
\hline Iron Oxide $\mathrm{Fe}_{2} \mathrm{O}_{3}$ & $0.5-0.6$ & 2.04 \\
\hline Magnesia $\mathrm{MgO}$ & $0.5-4$ & 1.74 \\
\hline Alkaline $\mathrm{K}_{2} \mathrm{O}, \mathrm{Na}_{2} \mathrm{O}$ & $0.3-1.2$ & 1.05 \\
\hline Sulfates $\mathrm{SO}_{3}$ & $1.0-3.0$ & - \\
\hline
\end{tabular}

\section{EXPERIMENTAL METHODOLOGY:}

\subsection{Water Absorption of Pervious Concrete: [IS: 2386 - (PART - III) 1963]}

The $100 \mathrm{~mm} \emptyset * 200 \mathrm{~mm}$ height cylinder after casting will be immersed in water for 28 days curing. These specimens will then oven dried for 24 hours at the temperature $110^{\circ} \mathrm{C}$ until the mass became constant and again weighed. This weight was noted as the dry weight (W1) of the block. After that the specimen will be kept in hot water at $85^{\circ} \mathrm{c}$ for 3.5 hours. Then this weight will noted as the wet weight (W2) of the block. The percentage Water Absorption (WA) is calculated as follows.

$$
\text { \% Water Absorption }=[(\mathrm{W} 2-\mathrm{W} 1) / \mathrm{W} 1] \times 100
$$

Where,

$\mathrm{W} 1=$ Oven dry weight of the cylinder in grams $\mathrm{W} 2=\operatorname{after} 3.5$ hour wet weights of cylinder in grams

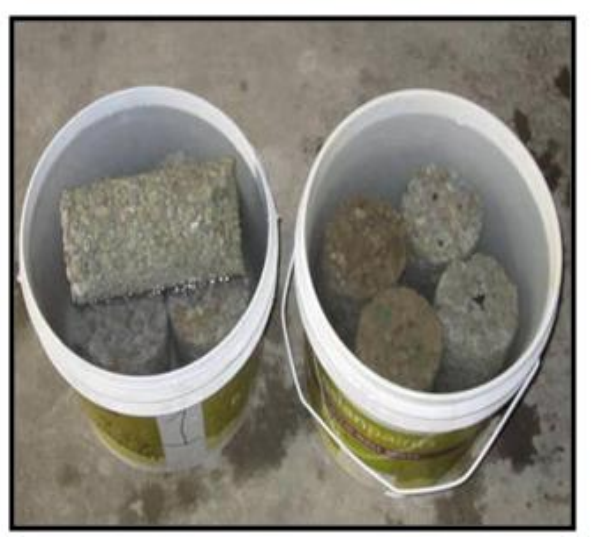

Fig 1: Water Absorption of Cylinders

\subsection{Durability (Sodium Chloride Solution) Test: [IS 445:2000]}

For the durability test the oven dried specimens having known volume will be weighted on the digital weighing machine and calculated to the mass of specimen per unit volume. 
To investigate the effect of sodium chloride solution the specimens will be tested for percentage change in weight after 28 days immersion in sodium chloride solution. Percentage change in weight determination will be carried out in the same manner as ofin the water absorption test. The schedule for casting and testing are as shown in fig .

The mix proportions for preparing a pervious concrete mixture, the planning for casting the numbers of blocks and scheduling for casting and testing of pervious concrete blocks are as follows.

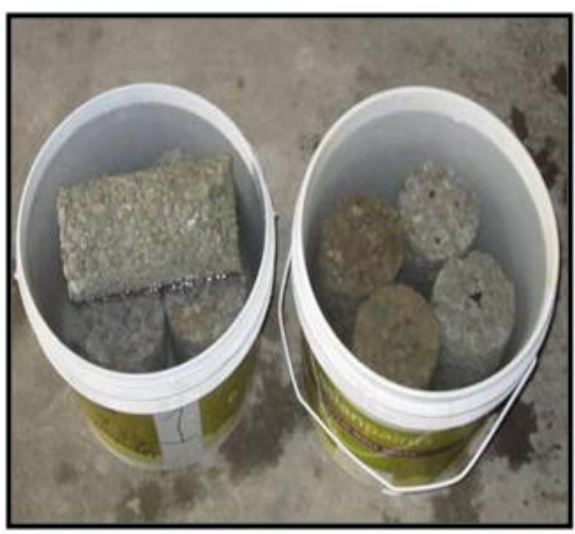

Fig 2: Cylinders Immersed in Sodium Chloride $(\mathrm{NaCl})$ Solution

\section{EXPERIMENTAL RESULTS:}

4.1 Water Absorption Test: [IS: 2386 - (PART - III) 1963]

Table 3: water absorption test results for cylinder (100 $\mathrm{mm} \varnothing$ * $200 \mathrm{~mm}$ height) with opc

\begin{tabular}{|c|c|c|}
\hline \multirow{2}{*}{$\begin{array}{c}\text { SIZES OF } \\
\text { GRAVEL }\end{array}$} & $\begin{array}{c}\text { CONCRETE } \\
\text { MIX }\end{array}$ & $\begin{array}{c}\text { 28 DAYS AVG } \\
\text { \% F WATER } \\
\text { ABSORPTION }\end{array}$ \\
\hline \multirow{3}{*}{$\begin{array}{c}\text { A: } 3 / 4 \text { inch } \\
(18.75 \mathrm{~mm})\end{array}$} & $\mathrm{A} 1(1: 6)$ & 0.65 \\
\cline { 2 - 3 } & $\mathrm{A} 2(1: 8)$ & 0.92 \\
\cline { 2 - 3 } & $\mathrm{A} 3(1: 10)$ & 1.08 \\
\hline \multirow{3}{*}{$\begin{array}{c}\text { B: } 3 / 8 \mathrm{inch} \\
(9.375 \mathrm{~mm})\end{array}$} & $\mathrm{B} 1(1: 6)$ & 0.29 \\
\cline { 2 - 3 } & $\mathrm{B} 2(1: 8)$ & 0.55 \\
\cline { 2 - 3 } & $\mathrm{B} 3(1: 10)$ & 0.68 \\
\hline
\end{tabular}

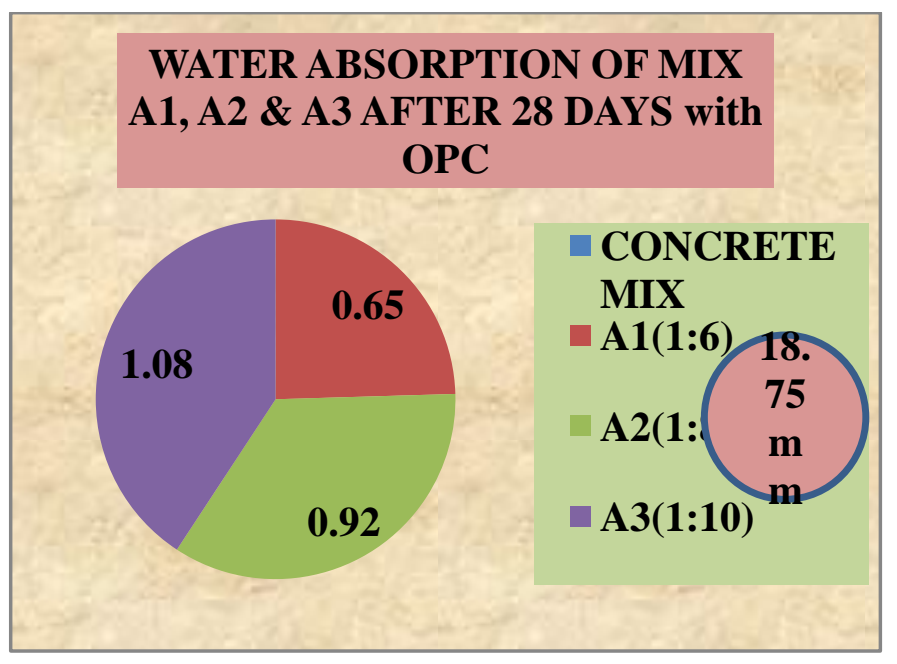

Fig 3: Water Absorption of Mix A1, A2 \& A3 after 28 Days with OPC for $18.75 \mathrm{~mm}$

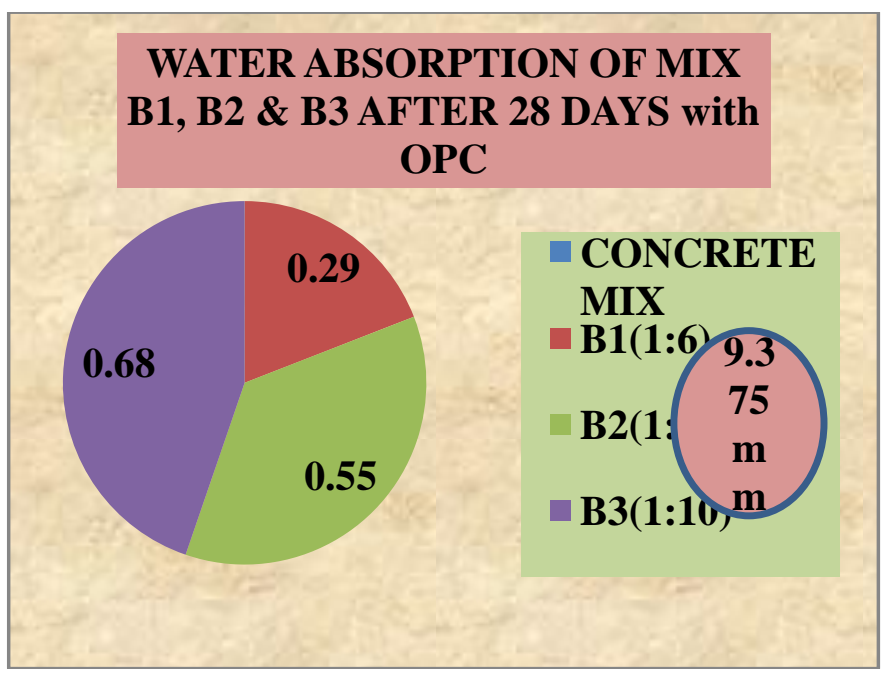

Fig 4: Water Absorption of Mix B1, B2 \& B3 after 28 Days with OPC for $9.375 \mathrm{~mm}$

Table 4: water absorption test results for cylinder (100 $\mathrm{mm} \varnothing$ * $200 \mathrm{~mm}$ height) with ppc

\begin{tabular}{|c|c|c|}
\hline $\begin{array}{c}\text { SIZES OF } \\
\text { GRAVEL }\end{array}$ & $\begin{array}{c}\text { CONCRETE } \\
\text { MIX }\end{array}$ & $\begin{array}{c}\text { 28 DAYS AVG \% } \\
\text { WATER } \\
\text { ABSORPTION }\end{array}$ \\
\hline \multirow{2}{*}{$\begin{array}{c}\text { A: } 3 / 4 \text { inch } \\
(18.75 \mathrm{~mm})\end{array}$} & $\mathrm{A} 1(1: 6)$ & 0.55 \\
\cline { 2 - 3 } & $\mathrm{A} 2(1: 8)$ & 0.88 \\
\cline { 2 - 3 } & $\mathrm{A} 3(1: 10)$ & 1.04 \\
\hline \multirow{2}{*}{$\begin{array}{c}\text { B: } 3 / 8 \mathrm{inch} \\
(9.375 \mathrm{~mm})\end{array}$} & $\mathrm{B} 1(1: 6)$ & 0.25 \\
\cline { 2 - 3 } & $\mathrm{B} 2(1: 8)$ & 0.48 \\
\cline { 2 - 3 } & $\mathrm{B} 3(1: 10)$ & 0.56 \\
\hline
\end{tabular}




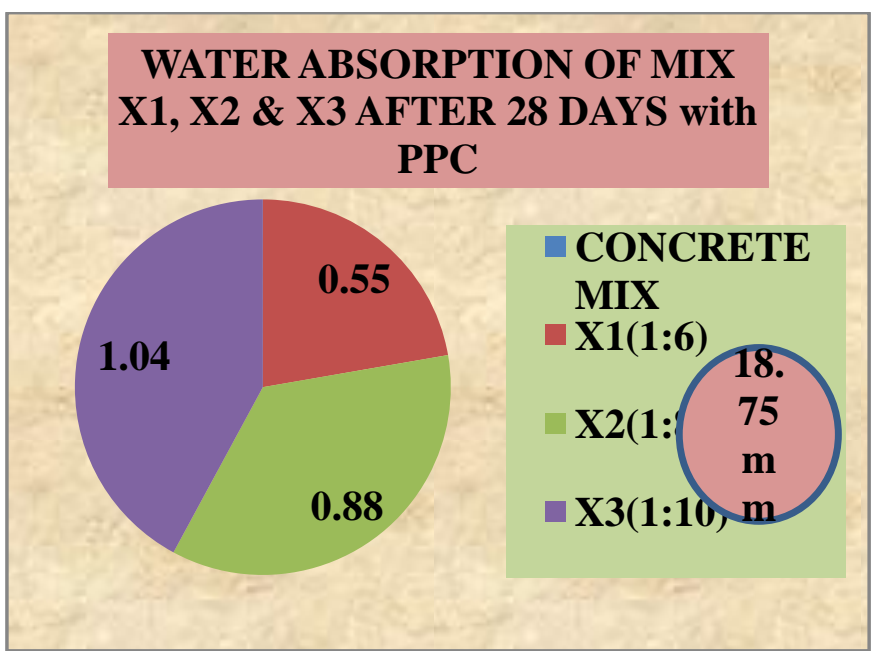

Fig 5: Water Absorption of Mix X1, X2 \& X3 after 28 Days with PPC for $18.75 \mathrm{~mm}$

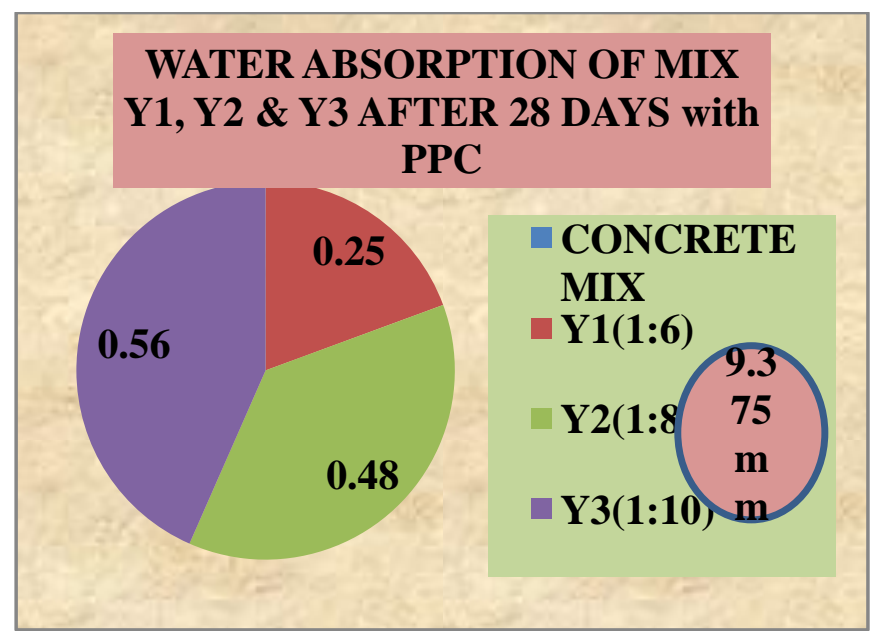

Fig 6: Water Absorption of Mix Y1, Y2 \& Y3 after 28 Days with PPC for $9.375 \mathrm{~mm}$

\subsection{Durability Test: [IS 445:2000]}

Table 5: durability test results for cylinder (100 mm $\varnothing * 200$ $\mathrm{mm}$ height) with opc

\begin{tabular}{|c|c|c|}
\hline $\begin{array}{c}\text { SIZES OF } \\
\text { GRAVEL }\end{array}$ & $\begin{array}{c}\text { CONCRETE } \\
\text { MIX }\end{array}$ & $\begin{array}{c}\text { 28 DAYS AVG \% } \\
\text { DURABILITY }\end{array}$ \\
\hline \multirow{2}{*}{$\begin{array}{c}\text { A: } 3 / 4 \mathrm{inch} \\
(18.75 \mathrm{~mm})\end{array}$} & $\mathrm{A} 1(1: 6)$ & 0.34 \\
\cline { 2 - 3 } & $\mathrm{A} 2(1: 8)$ & 0.30 \\
\cline { 2 - 3 } & $\mathrm{A} 3(1: 10)$ & 0.26 \\
\hline \multirow{2}{*}{$\begin{array}{c}\text { B: } 3 / 8 \text { inch } \\
(9.375 \mathrm{~mm})\end{array}$} & $\mathrm{B} 1(1: 6)$ & 0.36 \\
\cline { 2 - 3 } & $\mathrm{B} 2(1: 8)$ & 0.34 \\
\cline { 2 - 3 } & $\mathrm{B} 3(1: 10)$ & 0.32 \\
\hline
\end{tabular}

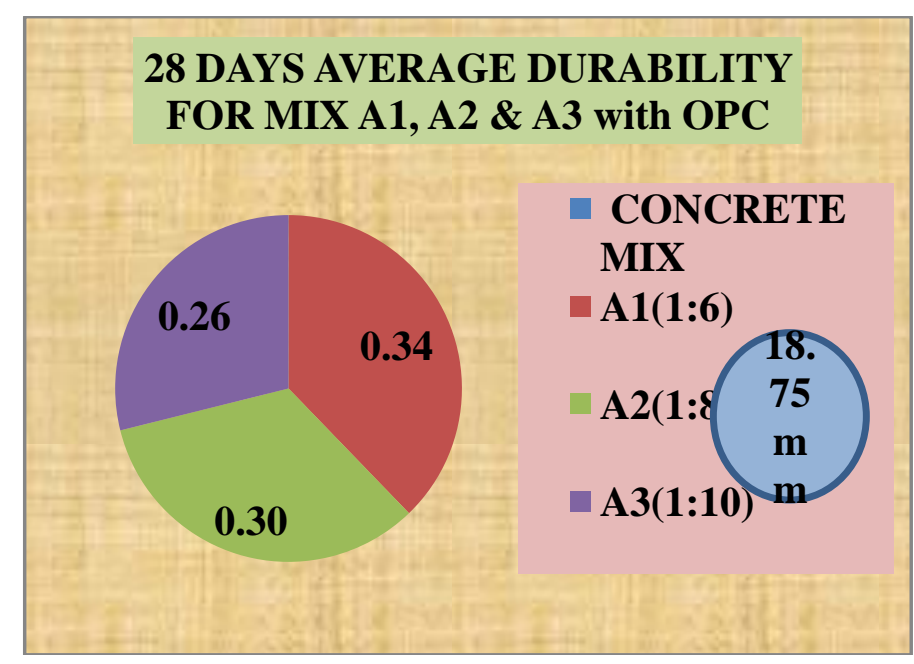

Fig 7: Durability of Mix A1, A2 \& A3 after 28 Days with OPC for $18.75 \mathrm{~mm}$

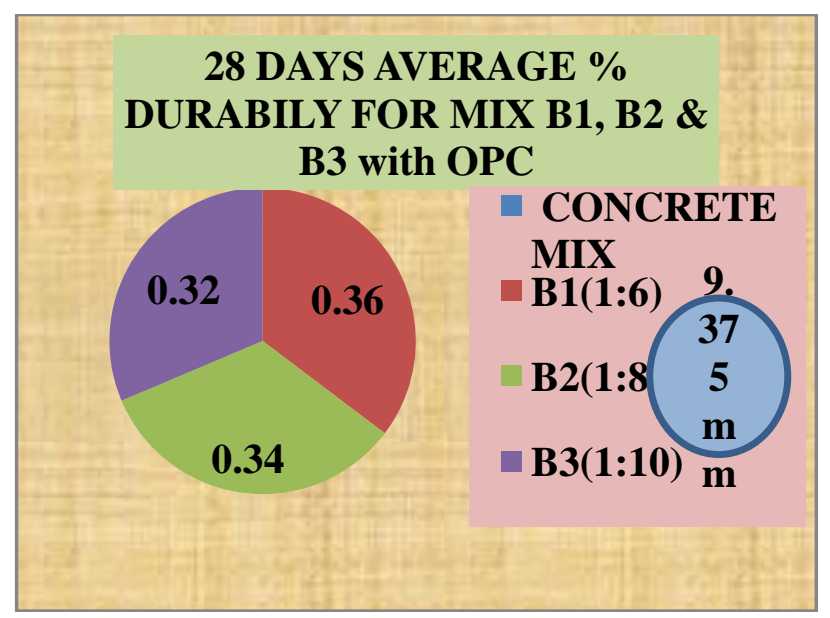

Fig 8: Durability of Mix B1, B2 \& B3 after 28 Days with PPC for $9.375 \mathrm{~mm}$

Table 6: durability test results for cylinder (100 mm $\varnothing * 200$ $\mathrm{mm}$ height) with ppc

\begin{tabular}{|l|c|c|}
\hline $\begin{array}{c}\text { SIZES OF } \\
\text { GRAVEL }\end{array}$ & $\begin{array}{c}\text { CONCRETE } \\
\text { MIX }\end{array}$ & $\begin{array}{c}\text { 28 DAYS AVG \% } \\
\text { DURABILITY }\end{array}$ \\
\hline \multirow{2}{*}{$\begin{array}{c}\text { A: } 3 / 4 \text { inch } \\
\left(\begin{array}{c}18.75 \\
\text { mm) }\end{array}\right.\end{array}$} & $\mathrm{A} 1(1: 6)$ & 0.30 \\
\cline { 2 - 3 } & $\mathrm{A} 2(1: 8)$ & 0.26 \\
\hline \multirow{2}{*}{$\begin{array}{c}\text { B: } 3 / 8 \text { inch } \\
\left(\begin{array}{c}9.375 \\
\mathrm{~mm})\end{array}\right.\end{array}$} & $\mathrm{A} 3(1: 10)$ & 0.25 \\
\cline { 2 - 3 } & $\mathrm{B} 1(1: 6)$ & 0.32 \\
\cline { 2 - 3 } & $\mathrm{B} 3(1: 10)$ & 0.29 \\
\hline
\end{tabular}




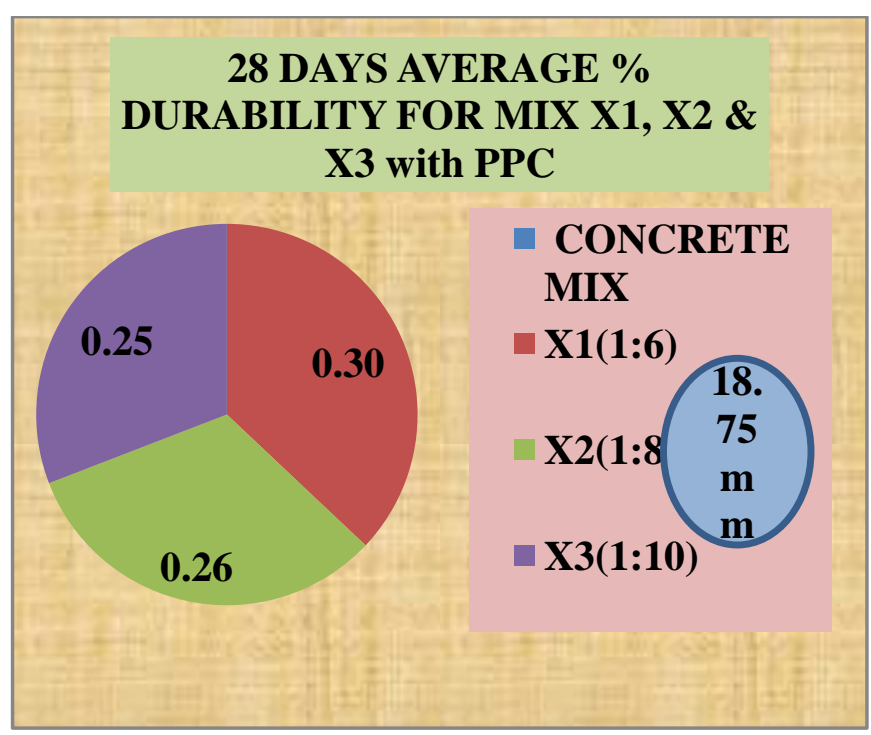

Fig 9: Durability of Mix X1, X2 \& X3 after 28 Days with OPC for $18.75 \mathrm{~mm}$

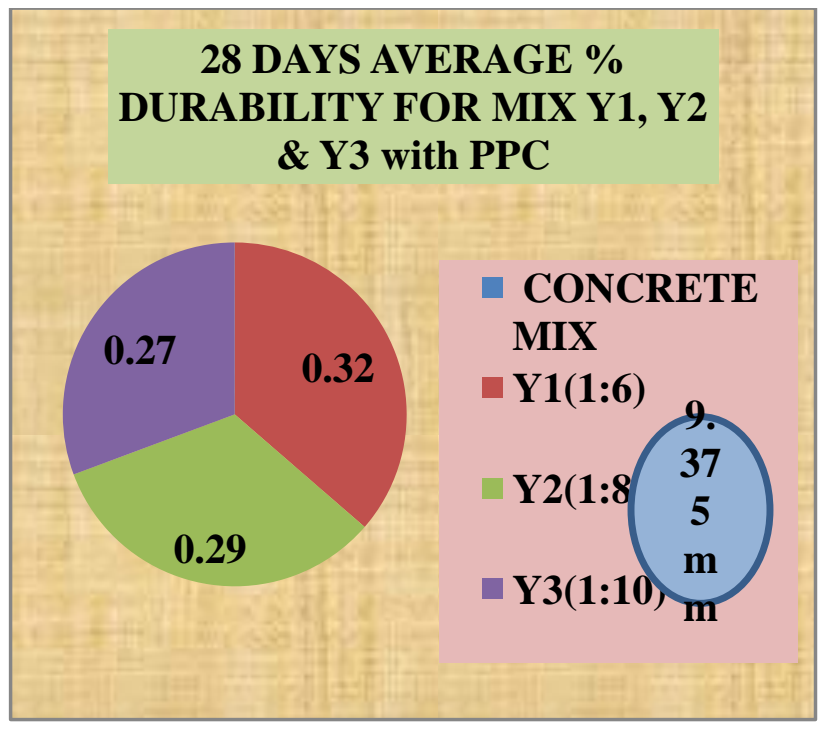

Fig 10: Durability of Mix Y1, Y2 \& Y3 after 28 Days with OPC for $9.375 \mathrm{~mm}$

\section{CONCLUSIONS:}

From the experimental result following conclusions were found out,

- $\quad 18.75 \mathrm{~mm}$ size gravel.with 1:10 mix proportion made with OPC has more water absorption percentage value $(1.08 \%)$ compared to other and similarly $9.375 \mathrm{~mm}$ size gravel with 1:10 mix proportion made with OPC has more water absorption percentage $(0.68 \%)$ compared to other .

- $\quad 18.75 \mathrm{~mm}$ size gravel with 1:6 proportion made with OPC is more duable $(0.34 \%)$ compared to other and similarly $9.375 \mathrm{~mm}$ size gravel with 1:6 mix proportion made with $\mathrm{OPC}$ is more durable $(0.36 \%)$ compared to other.
- From these conclusions one main result is found out such as, water absorption and durability are inversely proportional to each other means that, concrete made by 1:6 mix proportion has more durability and less water absorption and concrete made by 1:10 mix proportion has more water absorption and less durability.

\section{ACKNOWLEDGMENTS}

The Authors thankfully acknowledge to Dr. C. L. Patel, Chairman, Charutar Vidya Mandal, Er.V.M.Patel, Hon.Jt. Secretary, Charutar Vidya Mandal, Dr.F.S.Umrigar, Principal, B.V.M. Engineering College, Prof. J. J. Bhavsar, Associate Professor, PG Coordinator, Civil Engineering Department, B.V.M. Engineering College Vallabh Vidyanagar, Gujarat, India for their motivations and infrastructural support to carry out this research.

\section{REFERENCES:}

[1] Crouch, L. K., Pitt, J., and Hewitt, R. (2007). "Aggregate Effects on Pervious Portland Cement Concrete Static Modulus of Elasticity" J. Mater. Civ. Eng. 19(7), 561-568.

[2] Darshan S. Shah, Prof. J.R.Pitroda, "Pervious Concrete: New Era for Rural Road Pavement", International Journal of Engineering Trends and Technology (IJETT) ISSN No. 2231-5381, Volume: 4, Issue: 8, August 2013, Page: 3496 - 3500

[3] Darshan S. Shah, Prof. J.R.Pitroda, "Assessment for use of Gravel in Pervious Concrete", International Journal of Engineering Trends and Technology (IJETT) ISSN No. 2231-5381, Volume: 4, Issue: 10, Octomber 2013, Page: 4306 - 4310

[4] Ghafoori, N., and Dutta, S.(November 1995),"Building and Non pavement Applications of No-Fines Concrete," Journal of Materials in Civil Engineering, Volume 7, Number 4, pgs. 286-289.

[5] Khalfan, M. M. A., (2002) "Sustainable Development \& Sustainable Construction", Southborough University http://www.c-sand.org.uk/Documents/WP2001-02 Sustain Lit Rev.pdf Accessed: 25th June 2008

[6] Luck, J. D., Workman, S. R., Higgins, S. F, and Coyne, M. S. (2006). "Hydrologic properties of pervious concrete," Transactions of the ASABE, (Vol. 49), No. 6, pp 1807-1813

[7] Montes, F., Valavala, S., and Haselbach, L.M.(2005), "A New Test Method for Porosity Measurements of Portland Cement Pervious Concrete," Journal of ASTM International, Vol. 2, No 1, January 2005, pp.13 National Ready Mixed Concrete Association(NRMCA), (2004)"Freeze - Thaw Resistance of Pervious Concrete", Silver Spring, Maryland, May 2004, 17 pages

[8] National Ready Mixed Concrete Association(NRMCA), (2004) "What, Why, and How? 
Pervious Concrete", Concrete in Practice series, CIP 38, Silver Spring, Maryland, May 2004, 2 pages

[9] Park, S., Tia, M. (2004), “An experimental study on the water-purification properties of porous concrete," Cement and Concrete Research, (Vol. 34), pp.177-184.

[10] Richard c Meininger, (1988), "No Fines Pervious Concrete for Paving," Concrete International Vol. 10, No. 8, August 1988, pp. 20-27

[11] Rushton B., (2002) "Infiltration Opportunities in Parking-Lot Design Reduce Runoff and Pollution", Storm water, 2002

[12] Sneha Sanjay Ganpule, S. V. Pataskar (2011),"Use of Porous Concrete as a Green Construction Material for Pavement" International Journal of Earth Sciences and Engineering, ISSN 0974-5904, Volume 04, No 06 SPL, October 2011, pp. 764-767

[13] S.O. Ajamu, A.A. Jimoh, J.R. Oluremi (2012), "Evaluation of The Structural Performance of Pervious Concrete in Construction" International Journal of Engineering and Technology Volume 2 No. 5, May, 2012

[14] Sri Ravindrarajah R. and Aoki Y. (2008), "Environmentally friendly porous concrete", Proceedings of the Second International Conference on Advances in Concrete and Construction, Hydrabad, India, Feb 2008

[15] Yang, J., and Jiang, G. (2003), "Experimental Study on Properties of Pervious Concrete Pavement Materials". Cement and Concrete Research, V. 33, p. 381-386

\section{BIOGRAPHIES:}

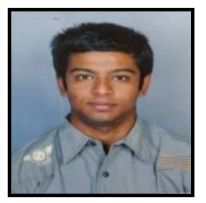

Darshan S. Shah was born in 1991 in Nadiad, Gujarat. He received his Bachelor of Engineering degree in Civil Engineering from the B.V.M. Engineering College, Gujarat Technological University in 2012. At present he is Final year student of Master`s Degree in Construction Engineering and Management from Birla Vishwakarma Mahavidyalaya, Gujarat Technological University. $\mathrm{He}$ is interested in research work on the durability properties of pervious concrete.

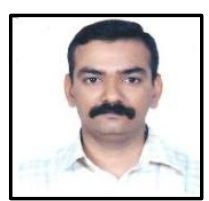

Prof. Jayeshkumar R. Pitroda was born in 1977 in Vadodara City. He received his Bachelor of Engineering degree in Civil Engineering from the Birla Vishvakarma Mahavidyalaya, Sardar Patel University in 2000. In 2009 he received his Master's Degree in Construction Engineering and Management from Birla Vishvakarma Mahavidyalaya, Sardar Patel University. He joined Birla Vishvakarma Mahavidyalaya Engineering College as a faculty where he is Assistant Professor of Civil Engineering Department with a total experience of 12 years in the field of Research, Designing and education. He is guiding M.E. (Construction Engineering \& Management) Thesis work in the field of Civil/ Construction Engineering. He has published papers in National Conferences and International Journals. 